\title{
MINERAL RESOURCE POTENTIAL OF THE DRAGOON MOUNTAINS ROADLESS AREA, COCHISE COUNTY, ARIZONA
}

\author{
By \\ Harald Drewes, K. C. Watts, Jr.y and D. P. Klein, U.S. Geological Survey \\ and \\ T. J. Kreidler, U.S. Bureau of Mines
}

\section{STUDIES RELATED TO WILDERNESS}

Under the provisions of the Wilderness Act (Public Law 88-577, September 3, 1964) and related acts, the U.S. Geological Survey and the U.S. Bureau of Mines have been conducting mineral surveys of wilderness and primitive areas. Areas officially designated as "wilderness," "wild," or "canoe" when the act was passed were incorporated into the National Wilderness Preservation System, and some of them are presently being studied. The act provided that areas under consideration for wilderness designation should be studied for suitability for incorporation into the Wilderness system. The mineral surveys constitute one aspect of the suitability studies. The act directs that the results of such surveys are to be made available to the public and be submitted to the President and the Congress. This report discusses the results of a mineral survey of the Dragoon Mountains Roadless Area, Coronado National Forest, Cochise County, Ariz. The Dragoon Mountains Roadless Area (03201) was classified as a further planning area during the Second Roadless Area Review and Evaluation (RARE II) by the U.S. Forest Service, January 1979.

\section{MINERAL RESOURCE POTENTIAL SUMMARY STATEMENT}

The Dragoon Mountains Roadless Area lies in the northern part of the Dragoon Mountains, near the southeast corner of Arizona. The roadless area lies between the village of Dragoon on the main line of the Southern Pacific Railroad to the north and a Cochise County road through Middle Pass to the south, and between the valley of the San Pedro River to the west and the Sulfur Springs Valley to the east (fig. 1).

Six areas, about 10 percent of the roadless area, have a moderate mineral resource potential; the remainder of the area has a low mineral resource potential (see fig. 2). The roadless area could contain metamorphic skarntype deposits of copper, lead, molybdenum, and zinc, and some of these could contain silver and gold. Less probably, the roadless area could also contain stockwork molybdenum deposits and replacement or vein deposits containing beryllium, fluorite, thorium, tin, and tungsten. The possibility for the presence of industrial rock material of value is moderate, and for gas or oil is low.

\section{INTRODUCTION}

The Dragoon Mountains of central Cochise County are one of a group of northwest-trending ranges in southeastern Arizona. The Dragoon Mountains have a broad, low southeastern part; a narrow, moderately high central part; and a broad, high, northwestern part. The Dragoon Mountains Roadless Area, about $55 \mathrm{mi}^{2}(140 \mathrm{~km})$ in size, covers most of this northwestern part. The roadless area thus extends from Middle Pass in the southeast to Big Draw in the northwest, and from the edge of Sulphur Springs Valley in the northeast to the edge of the San Pedro River Valley in the southwest, excluding several canyon mouths and other developed areas, as shown on figure 1.

Access to the roadless area is from the towns of Willcox, $15 \mathrm{mi}(25 \mathrm{~km})$ northeast, or Tombstone, $10 \mathrm{mi}$ $(16 \mathrm{~km})$ southwest, or from the villages of Pearce, $6 \mathrm{mi}$ $(10 \mathrm{~km})$ southeast, or Dragoon, $2 \mathrm{mi}(3 \mathrm{~km})$ north of the mountains. There are county roads across Middle Pass and past the north end of the range in a lowland also used by the Southern Pacific Railroad. Interstate Highway 10 is $5 \mathrm{mi}(8 \mathrm{~km})$ north of the range and U.S. Highway 666 comes to within $6 \mathrm{mi}(10 \mathrm{~km})$ of the northeast side. Additional local roads provide access to ranches and recreation areas in the lower reaches of major canyons and unmaintained roads extend well into the roadless area in several places.

The core of the mountains is rugged and in places is steep and craggy. The foot of the range is at elevations of $4,500-5,000 \mathrm{ft}(1,500 \mathrm{~m})$; the highest peak, Mt. Glenn, reaches $7,512 \mathrm{ft}(2,300 \mathrm{~m})$. The highest slopes are covered with fairly dense stands of scrubby mountain mahogany, but most of the slopes have more open stands of juniper, pinon, or oak. On the lower mountain flanks access is rarely hindered, and the vegetational cover is largely grass, shrubs, cactus, and open stands of live oak.

This report describes the mineral resource potential of the roadless area, which is based on separate reconnaissance studies of the geology, mines, 


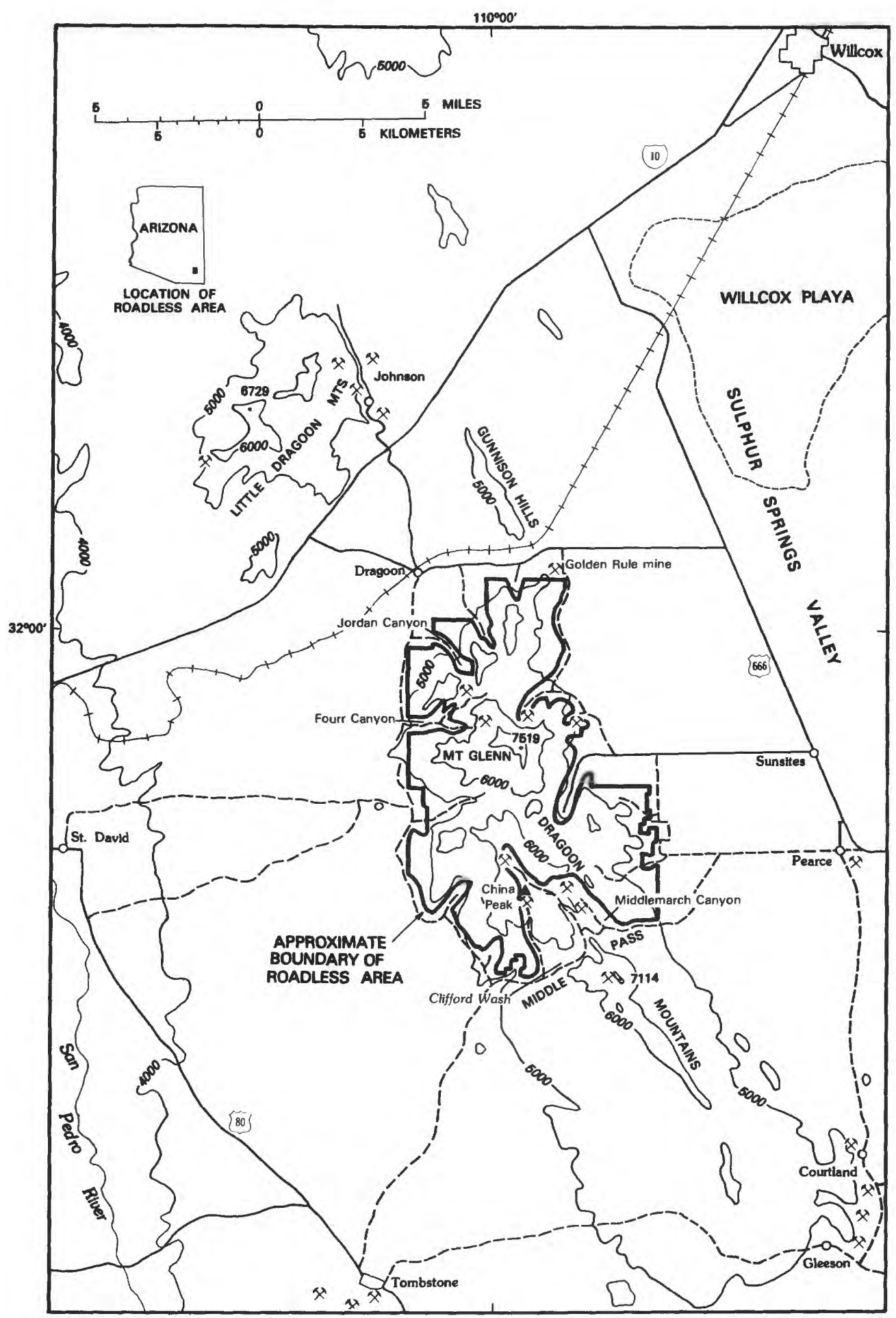

Figure 1.-Map showing location of the Dragoon Mountains Roadless Area (03201). 

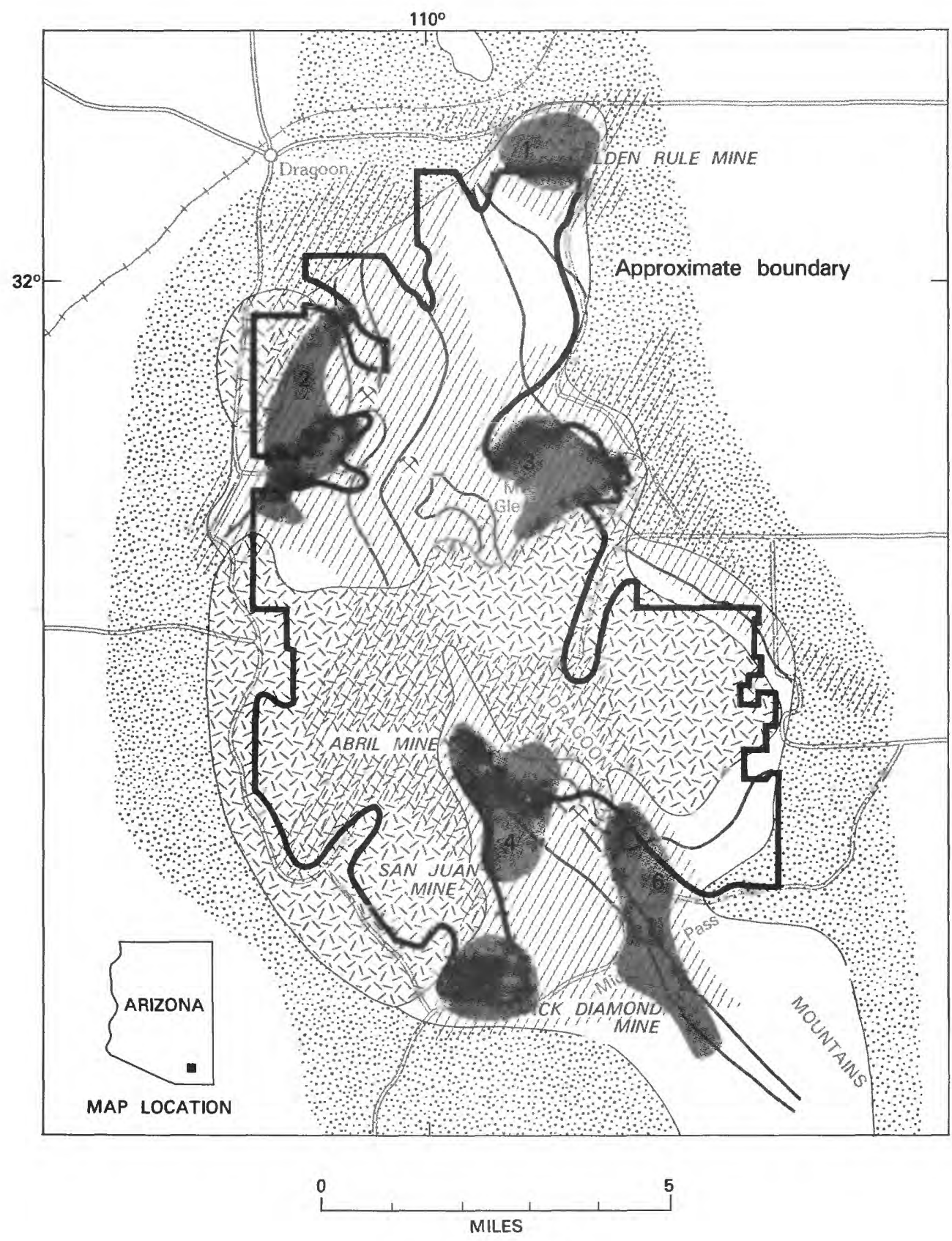

\section{EXPLANATION}

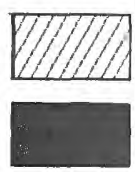

父
Geologic terrane having low mineral resource potential

Geologic terrane having moderate mineral resource potential

\section{Mine}

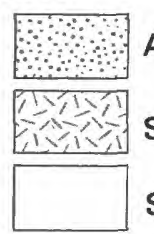

Alluvium on gravel (Quaternary)

Stocks, mainly granite (Tertiary)

Sedimentary and metasedimentary rocks (Mesozoic, Paleozoic, and Precambrian)

\section{Contact}

Fault

2 Location discussed in text

Figure 2.-Map showing simplified geology and areas having mineral resource potential in the Dragoon Mountains Roadless Area (numbered areas are referred to in the text). 
geochemistry, and geophysics. The geologic study includes mapping, petrographic examination of key igneous rocks, and some rock dating through fossil examination and radiometric methods (Drewes and Meyer, in press). The mine study covers a compilation of mining property and a review of mining history and production, as well as examining and assaying samples from mines not previously studied (Kreidler, in press). Geochemical studies include spectrographic analyses of mineralized chip samples and of alluvial samples (Watts and others, in press; Drewes, in press). Geophysical studies include airborne gravity and magnetic surveys (Klein, in press). The conclusions of these separate studies are combined and incorporated in our assessment of the roadless area, given in this report.

\section{GEOLOGY}

The Dragoon Mountains Roadless Area is underlain by a wide variety of rock types, many of which are metamorphosed and most of which are strongly faulted. Some fault blocks contain exposed metamorphic or granitic basement rocks. These rocks are overlain by thick sequences of sedimentary and metasedimentary rocks of Paleozoic and Mesozoic ages. Several stocks, plugs, and swarms of dikes, of Tertiary age, intrude the basement rocks and their covering sequences. Gravel deposits of Tertiary and Quaternary ages overlap the older rocks along the mountain flanks and fill the adjacent basins. Just south of the roadless area volcanic rocks are associated with the Tertiary gravel deposits, and they could as well underlie the valleys adjacent to the roadless area.

The Precambrian basement is made up of schist, arkose, quartzite, sedimentary breccia, conglomerate, metavolcanic rocks, amphibolite, and large plutons of granodiorite. These rocks rarely contain metallic minerals in the roadless area.

The Paleozoic and Mesozoic sedimentary and metasedimentary cover sequences are each 6,500$8,000 \mathrm{ft}(2,000-2,500 \mathrm{~m})$ thick. Thick Paleozoic sequences are largely composed of limestone, but shale, sandstone, and some conglomerate are intercalated with limestone in the lower and upper parts of the sequences. The rocks in the lower part of the sequences that are of mixed lithology (Abrigo and the Martin Formations), are important host rocks to mineral deposits in the region. The Mesozoic sequence is mainly shale and sandstone, but locally has interbedded limestone, basal limestone conglomerate, and a capping unit of volcaniclastic conglomerate. Some of these rocks also contain metallic minerals.

Tertiary intrusive rocks include a small stock of granite $37 \mathrm{~m} . \mathrm{y}$. (million years) old, two plugs of rhyolite of this age or older, a larger granite stock known as the Stronghold stock (20-27 m.y. old), and many dikes, including a swarm of rhyolite dikes that are less than about $20 \mathrm{~m} . \mathrm{y}$. old. These intrusive rocks are also associated with mineralized rocks. Another granite stock about $50 \mathrm{~m} . \mathrm{y}$. old lies just north of the roadless area, adjacent to the Johnson mining district.

Tertiary and Quaternary gravel barely extend into the roadless area, forming stream terrace, pediment deposits, and basin-fill deposits. A pediment of unknown but perhaps considerable width is cut on the west flank of the Stronghold stock. The geophysical surveys have not helped to mark the extent of the pediment there, but they show moderately deep anomalies that may mark the edge of the stock, outside the roadless area.

Few mountain ranges in southeastern Arizona contain rocks as strongly deformed as those in the Dragoon Mountains. Faults are particularly abundant in the roadless area, and in places the rocks are also folded. Typically, the faults are steep and trend northwest, but near the north end of the range they trend more nearly north. Gently inclined faults are also common, and some of these merge with steep faults. Nearly all faults are older than the Tertiary stocks, and thus they were available as conduits for fluids moving away from the stocks, some of which may have carried metals.

The regional setting of the rocks and structures described above have been described by Gilluly (1956), Cooper (1960), and Drewes (1980 and 1981). These studies conclude that many of the structural features were formed as a result of horizontally directed forces, typically oriented east-northeast, but another, local, study (Keith and Barnett, 1976) emphasizes vertical movements. These alternate interpretations of the structures are significant to their origin, but have little bearing on this assessment of the mineral potential of the roadless area.

Intrusive bodies can influence movement of mineralizing fluids as well as supplying ore-forming material and energy to many kinds of mineralizing systems. A common result of intrusion is the development of a halo of metamorphosed rocks around a stock. Near the stocks of the roadless area, the contact metamorphosed wall rocks also contain skarntype alteration where mines and prospects are located. The walls of the stocks of the Dragoon Mountains have irregular attitudes, dipping steeply in some places and dipping gently outward in others. Consequently, some parts of the contact metamorphic zones and potentially mineralized rocks are narrow and others are broad. The gently dipping outward stock walls are of special interest in assessments of mineral potential because ore fluids tend to accumulate there.

The geologic map of the roadless area was combined with the other studies at two levels of report preparation. Each of the studies made use of such geologic data as the distribution of faults, intrusive bodies, and host rocks favorable for having mineral deposits. For example, the boundary delineating potentially mineralized ground around a cluster of prospects showing anomalous silver values within a particular fault block is placed just outside the bounding faults rather than within them. Likewise, in areas near a stock having favorable magnetic or gravity anomalies the borders of potentially mineralized ground are extended outward toward major faults cut by the stock. After the results of the separate studies were blended to show terranes of similar potential on a single map, the boundaries between these terranes were adjusted slightly to better reflect features such as dips on faults or subsurface projections of favorable host rocks. At this stage, too, more detailed mapping (scale 1:24,000) that is not part of this report, was utilized (Harald Drewes, unpub. mapping, 1982). This mapping shows many more map units, faults, dikes, and structural data. 


\section{GEOCHEMISTRY}

A geochemical study, based on analyses of alluvial samples, was made by Watts and others (in press) of the U.S. Geological Survey. This reconnaissance study provides a view of the distribution of many kinds of ore minerals and of indicator or guide minerals, both in areas of old prospecting and in other areas. As a result of this study, some small drainage basins are recognized as having a potential for skarn-type replacement deposits; other areas could contain stockwork-greisen molybdenum deposits, based on the distributions in unusual amounts of such metals as tungsten, molybdenum, boron, lead, silver, tin, thorium, and beryllium. The possibility for certain deposit types is indicated by the kind of minerals found and their dispersal, as compared to geochemical relationships observed in mining districts in Arizona and New Mexico having similar geologic conditions and to relationships found in other deposits of the world.

A geochemical study of mineralized rock chips, mainly from the many small prospects in the roadless area, but also from outcrops lacking prospects, was made by Drewes (in press) of the U.S. Geological Survey. Some of the samples were taken from mine dumps from which assays were obtained; most samples were taken from dumps of prospects that were not mapped or sampled for assay. Some prospects are in drainage basins that were sampled as a part of the alluvial study; other prospects are along larger canyon drainages that were not covered by the alluvial study. Consequently, this study complements the other geochemical studies. Furthermore, the techniques used in the collection and preparation of samples differed among the geochemical studies, and the factors of natural dilution from a single prospect and of artificial concentration by gold panning lead to different kinds of results for the separate studies. The main value of this study is to identify the presence in visibly mineralized rocks of metals or indicator elements, whose specific mineral occurrence is difficult to determine in the field. For example, silver is difficult to detect in the field where it is part of the lead mineral, galena. Samples from many of these mineralized rocks were tested also by atomic absorption methods for a few elements (gold for example), which are not satisfactorily determined by spetrographic analyses.

\section{GEOPHYSICS}

The geophysical study covers airborne magnetometer and gravity surveys interpreted by Klein (in press) of the U.S. Geological Survey. Using the distribution, shape, and intensity of anomalies, a map was prepared showing suspected stocks and faults, from which potentially mineralized zones are inferred. Of particular interest were those geophysical anomalies that indicate features, such as gently dipping outward walls of stocks or fault intersections, which, from experience in nearby mining districts, are likely to be associated with mineral deposits.

\section{MINING DISTRICTS AND MINERALIZATION}

A study of the mines and major prospects was made by Kreidler (in press) of the U.S. Bureau of Mines. Where previous work was unavailable, maps were made of accessible mines and bulk-sample assays were obtained from mineralized rock. Mining production records were sought, and county records were searched for patented and unpatented mining claims. This study shows that base and precious metals were mined in small or moderate quantities from several sites in or near the roadless area. These deposits are skarn-type replacements of limestone and limy shale near granite. Areas of this rock association were delineated and are considered to have a moderate potential for deposits similar to the known deposits, which are of small or moderate size.

Ores, chiefly of base metals and silver, have been produced from several mines and mining camps near the Dragoon Mountains Roadless Area. At Johnson, 2-2.5 mi (3-4 km) north of Dragoon, production of such ores from a geologic setting much like that of the roadless area probably exceeded a value of $\$ 10$ million. At Pearce, $4-5 \mathrm{mi}(7-8 \mathrm{~km})$ southeast of the roadless area, similarly large values of silver were produced from rocks having a volcanic setting unlike that of the roadless area. At Black Diamond, a mining camp $2 \mathrm{mi}(3 \mathrm{~km})$ south of Middle Pass, about $\$ 0.5$ million of copper and a little silver were produced from replacement deposits which appear to have a geologic setting that resembles some parts of the roadless area.

The Dragoon and Middle Pass mining districts lie, respectively, in and near the northeastern and the southern parts of the roadless area. In both districts the major production was from mines outside of the roadless area, although the districts themselves extend into the roadless area. Total production from the Dragoon mining district was about $\$ 340,000$ (Keith, 1973), mainly in gold, silver, and lead; most of the production came from fissure veins in the Golden Rule mine. Aggregate production from the Middle Pass mining district was about $\$ 1.7$ million (Keith, 1973), mainly from lead, zinc, copper, and lesser silver, gold, and tungsten mined from the Abril, San Juan, and Middle March mines. Typically these deposits were in mantos and chimneys of skarn-type replacement deposits in Paleozoic limestone and shale formations near the Stronghold stock.

The map (fig. 2) shows six areas, each a few square miles $(5-8 \mathrm{sq} \mathrm{km})$ in extent, that have a moderate mineral resource potential; a larger area has a low mineral resource potential. Some areas of moderate mineral resource potential lie largely within the roadless area; others are largely outside it but provide a basis for understanding the mineralization of the entire region because they are geologically similar to some areas within the roadless area.

\section{ASSESSMENT OF MINERAL RESOURCE POTENTIAL}

About 10 percent of the roadless area has a moderate mineral resource potential, whereas the 
mineral potential in the remainder of the area is low. Additional exploration efforts are justified in those areas of moderate mineral resource potential, described in the following section. The exploration should be preceded by more detailed geologic, geochemical, and geophysical studies.

The individual studies from which this assessment was made are published as separate parts of this report. All parts are given a number in common; each is separately identified by suffixed letter symbol. Basic analytic data are partly presented in the separate accounts and the locations of repositories of other data not reported in these accounts are identified in them.

The mineral potential of the roadless area is moderate for deposits like those of the nearby mining camps. Small bodies of lead, zinc, copper, and silver ores, as replacement bodies, fissure deposits, or skarntype deposits, can be expected to be present along certain segments of the stocks. The deposits could also contain gold, tungsten, tin, beryllium, and thorium, which occur in anomalous amounts in some of the mines and prospects of the roadless area. In addition, molybdenum stockwork deposits may be present in the roadless area, based on geochemical anomalies of that metal and on comparison with known molybdenum in similar geologic settings. Areas of moderate potential lie near stocks where concealed extensions of the stocks are likely to be shallow and where the Abrigo and Martin Formations could be present, or where faults are particularly abundant.

\section{Base and precious metals}

Six areas believed to have moderate mineral resource potential are shown on figure 2 . These areas are discussed below in an arbitrary order not meant to imply their relative favorability.

Area 1 is centered around the Golden Rule mine and lies largely outside the roadless area. At this area, two plugs of rhyolite porphyry intrude limestone, shale, and dolomite beds in the lower part of the Paleozoic sequence (specifically the Abrigo and Martin Formations and the Escabrosa Limestone) near the intersection of north-trending thrust faults and eastnortheast-trending strike-slip faults. Both sets of faults dip at moderate or high angles. From the intensity and extent of metamorphism around the stocks, these plugs are inferred to be the upper tips of a larger concealed stock. The rhyolite is strongly altered, apparently by the fluids associated with the dominantly lead, silver, and gold mineralization in this mining camp. Gold values as high as $2.5 \mathrm{ppm}$ (parts per million), or slightly less than $0.1 \mathrm{oz}$ per ton, were obtained in one of the chip samples from a mine dump. Aeromagnetic and gravity anomalies also suggest that this area may be underlain by a stock and may lie along a major fault roughly following the line of the railroad north of area 1. A branch of this fault is mapped along the northern foot of the Dragoon Mountains, about in line with one of the plugs. The rock formations and thrust faults within the Dragoon Mountains dip moderately westward.

The combination of geologic, geochemical, and geophysical observations, noted above, suggest that area 1 may contain additional mineral deposits of moderate or small size. While much of area 1 lies outside of the roadless area, the favorable rock types dip beneath a corner of the roadless area, and the faults that cut these rocks likewise project into the area. Consequently deep exploration efforts may be justified, particularly southwest of the existing mines and igneous plugs.

Area 2 lies along the northwest side of the Dragoon Mountains, between Fourr and Jordan Canyons, and is mainly within the roadless area. Several small mines, some of which are in the roadless area, are present. Area 2 is on the southeast side of a 37-m.y.-old stock that intrudes Precambrian phyllite, quartzite, and sedimentary breccia. The host rocks of the stock also include some limestone and shale of Paleozoic age, which are typically slivers of rock along north- to northeast-trending steep faults. Several intrusive bodies of aplite (a quartz- and feldspar-rich granite) related to the stock, are along these faults, suggesting that the roof of the stock dips gently southeast in this area, and perhaps dips more steeply beyond. A geophysical anomaly over the stock also suggests that the body may have a shoulder on its southeast side. Finally, area 2 has been extended slightly south of the mouth of Fourr Canyon, because of a strong southwest-trending fault zone and a remarkable upwarped and upfaulted feature along which there is some mineralized rock. Geochemical anomalies in this site are moderately widespread and far exceed known mineralized areas.

Area 2 has a moderate mineral resource potential for skarn-type deposits near the stock or replacement-type deposits containing lead, zinc, silver, and possibly tungsten in blind fault slices of limestone. Closer spaced geochemical sampling near the fault zones is possibly warranted, with a potential for finding enrichment of base metals and silver, or possibly, stockwork molybdenum or tungsten deposits.

Area 3, along the east side of the Dragoon Mountains immediately north of the Stronghold stock and the mouth of Stronghold Canyon East, is mainly within the roadless area. The topographically lower northern and eastern parts contain scattered mineral prospects. The area is underlain mainly by Paleozoic metasedimentary rocks that lie above a gently north dipping shoulder of the stock. Rocks in the lower part of the Paleozoic sequence lie close to the contact of the stock and are strongly metamorphosed, as well as thrust faulted. Those in the upper part of the Paleozoic sequence are less metamorphosed and are cut by intersecting high-angle faults and dikes. Geochemical anomalies, particularly base metals and silver, are widespread in the area, and a magnetic anomaly extends into the northeast part and probably continues through it, but the source of the anomaly appears to be quite deep within area 3 itself.

This area has a moderate mineral resource potential because of the combination of favorable geology and geochemistry, and apparently favorable geophysics. Base metals and silver concentrations could be in the Abrigo and Martin Formations, either near cross faults at the surface or down dip to the north. Additionally, the down-dip structural projections of intersecting faults and dikes, possibly at stratigraphic levels of skarn-rich formations, could be the loci for mineral concentrations.

Area 4 is situated on the prong of host rock separating two lobes of the Stronghold stock that projects southeast from the main body. The area contains the Abril and the San Juan mines near Gordon 
Camp, and lies largely outside of the roadless area. These mines develop skarn-type replacement bodies containing base metals and silver in faulted Paleozoic limestone near the stock. Area 4 is marked by a north-trending linear magnetic anomaly and several geochemical anomalies, one of base metals, tungsten, and silver trending northwest along the faulted rocks of the range crest, and the other of thorium, tin, and beryllium trending northeast across the range. Analyses of mineralized material in some of the mines and prospects in this area and previous studies of deposits in other mines are also favorable criteria.

We conclude from our studies and those reported previously that concentrations of base metals and silver similar to those just outside the roadless area could be present in area 4. They might have occurred preferentially near the stock and along steep faults in the host rock, which seems to have a configuration of the prow of a ship heading northwestward in a sea of granite. This granite is of particular interest because it contains a trace amount of primary fluorite, is very alkalic and younger than most mid-Tertiary stocks of the region, and contains anomalous values of tin, tungsten, thorium, and beryllium. Uranium is also suspected to be concentrated here, but its presence has not yet been substantiated by analysis. These elements may be associated with late-phase dikes near the mouth of Slavin Canyon, (Harald Drewes, unpub. mapping, 1982).

Further exploration in the area lying southwest of China Peak and north and northeast of Cochise Peak is justified.

Area 5 includes some of the southwestern part of the roadless area near the Sala Ranch as well as some ground adjacent to the roadless area. The area lies along the margin of the Stronghold stock, where the contact dips gently outward beneath a host of Paleozoic sedimentary rocks. These rocks are largely limestone but include the mixed lithologies of the Abrigo and Martin Formations. Host rocks are faulted and metamorphosed. Prospects are found in several parts of the area and show concentrations of base metals, silver, and tungsten. The linear magnetic anomaly of area 4 extends across part of area 5 as well.

A moderate mineral resource potential for skarntype deposits containing base metals, silver, and tungsten is assigned to area 5. Mineralized rock can preferentially be expected in the down-dip extension of the Abrigo Formation beneath the limestone ridge in the center of the area, and near some of the faults. The deposits probably are small, but silver values may be high, which would justify exploration in area 5.

Area 6 lies almost entirely outside the southern boundary of the roadless area, extending from Middlemarch Canyon to south of the Black Diamond mine. The site is underlain mainly by Precambrian basement rocks and Paleozoic and Mesozoic sequences. The Stronghold stock lies immediately north of the area and dikes cut rocks of area 6 . In general, metamorphism is not pronounced in these rocks and the mines and prospects in the area are on or near a strongly developed northwest-trending set of faults. Part of the area coincides with a magnetic anomaly; elsewhere the anomaly occurs with geologically less attractive ground. Small deposits of base metals and silver and some of tungsten were mined outside of the roadless area, and geochemical anomalies of these metals suggest their presence elsewhere in area 6.

Similar deposits could be present along faults in area 6, and we suggest that the fault set along Middlemarch Canyon near or along the roadless area boundary deserves further exploration.

\section{Industrial minerals and rocks}

The potential for the occurrence of industrial minerals and rocks is low to moderate, with the northern part of the roadless area between Fourr Canyon and the Golden Rule mine having the higher potential. This area is more favorable because it contains several commodities of possible value and it has excellent access to roads and railroad. Of likely interest are marble for flux, crushed rock, possible dimension stone, lime rock, and silica rock for flux.

Marble is found in several canyons near the north end of the range, especially between Jordan and Wood Canyons. Some marble has been quarried there, as well as $1 \mathrm{mi}(1-2 \mathrm{~km})$ southwest of the Golden Rule mine, but these quarries are too shallow to assess the quality of the rock for use in dimension stone. The favorable rock types are the Escabrosa and Horquilla Limestones, which are in thrust-faulted structural lenses and probably have a strong internal crystal fabric.

Lime rock for cement manufacture may occur between Jordan Canyon and area 1. The metamorphosed Paleozoic limestones, particularly the Horquilla Limestone may warrant testing; similarly metamorphosed Horquilla is utilized for cement production near Tucson. The distribution of this limestone is shown on maps by Gilluly (1956) and Drewes and others (1982, fig. 20). Apparently a critical factor is the abundance of chert nodules and their changes through metamorphism. Because of proximity to good transportation, the northern part of the roadless area warrants exploration for suitable lime rock.

Silica rock for flux may be present along the west flank of the mountains near the mouth of Fourr Canyon. Such rock is used in copper smelters in moderate amounts, typically from local sources that include quarried rock as well as rock scraped from talus and colluvial accumulations at the surface. A siliceous rock that may be suitable for flux is a quartzite member of the Pinal Schist. The quartzitic rock typically forms blocky detritus that veneers the interbedded phyllite beds. There are two smelters within $60 \mathrm{mi}(100 \mathrm{~km})$ of the roadless area.

\section{Petroleum and natural gas}

The Dragoon Mountains Roadless Area lies within a region currently being explored for oil and gas, following a concept of deep targets beneath thrust faults. Deep seismic techniques have provided new data enabling oil companies to project into the subsurface structures seen at the surface only incompletely and at large intervals in some of the ranges. These seismic records were not available to us for our assessment. The available geologic maps of the region around the roadless area show that the terrane has many thrust faults (Cooper, 1960; Cooper and Silver, 1964; Gilluly, 1956; Drewes, 1980, 1981; 
and Drewes and Meyer, (in press), and provide bases for projection of some subsurface structures. These regional geologic maps show where the rocks are especially strongly faulted and intruded by stocks whose heat may be expected to have driven off oil and gas accumulations trapped before stock emplacement. The potential for the occurrence of oil and gas is low.

\section{REFERENCES}

Cooper, J. R., 1960, Reconnaissance geologic map of the Willcox, Fisher Hills, Cochise, and Dos Cabezas quadrangles, Cochise and Graham Counties, Arizona: U.S. Geological Survey Mineral Investigations Field Studies Map MF-231, scale $1: 62,500$.

Cooper, J. R., and Silver, L. T., 1964, Geology and ore deposits of the Dragoon quadrangle, Cochise County, Arizona: U.S. Geological Survey Professional Paper 416, 196 p.

Drewes, Harald, 1980, Tectonic map of southeast Arizona: U.S. Geological Survey Miscellaneous Investigations Series Map I-1109, scale 1:125,000. 1981, Tectonics of southeastern Arizona: U.S. Geological Survey Professional Paper 1144, 96 p. in press, Reconnaissance geochemical maps of mineralized rocks of the Dragoon Mountains Roadless Area, Cochise County, Arizona: U.S. Geological Survey Miscellaneous Field Studies Map MF-1521-D, scale 1:50,000.
Drewes, Harald, and Meyer, G. A., in press, Geologic map of the Dragoon Mountains Roadless Area, Cochise County, Arizona: U.S. Geological Survey Miscellaneous Field Studies Map MF-1521-A, scale 1:50,000.

Drewes, Harald, Keith, S. B., LeMone, D. V., Seager, W. R., Clemons, R. E., and Thompson, Sam, III, 1982, Styles of deformation in the southern Cordillera, U.S.A. in Drewes, Harald ed, Cordilleran overthrust belt, Texas to Arizona Field Conference: Denver, Colorado, Rocky Mountain Association of Geologists, p. 1-86.

Gilluly, James, 1956, General geology of central Cochise County, Arizona, with sections on Age and correlation, by A. R. Palmer, J. S. Williams, and J.B. Reeside, Jr.: U.S. Geological Survey Professional Paper 281, 169 p.

Keith, S. B., 1973, Index of mining properties in Cochise County, Arizona: Arizona Bureau of Mines Bulletin 187, $98 \mathrm{p}$.

Keith, S. B., and Barnett, L. F., 1976, Tectonics of the central Dragoon Mountains-A new look: Arizona Geological Society Digest, v. 10, p. 169204.

Klein, D. P., in press, Geophysical maps of the Dragoon Mountains Roadless Area, Cochise County, Arizona: U.S. Geological Survey Miscellaneous Field Studies Map MF-1521-C, scale 1:50,000.

Kreidler, T. J., in press, Mine and prospect map of the Dragoon Mountains Roadless Area, Cochise County, Arizona: U.S. Geological Survey Miscellaneous Field Studies Map MF-1521-F.

Watts, K. C., Hassemer, J. R., Erickson, M. S., and Drewes, Harald, in press, Geochemical maps of the Dragoon Mountains Roadless Area, Cochise County, Arizona: U.S. Geological Survey Miscellaneous Field Studies Map MF-1521-E. 